\title{
ANALISIS MIKROPLASTIK PADA KERANG KIJING (Pilsbryoconcha exilis) DI SUNGAI PERANCAK, JEMBRANA, BALI
}

\author{
Agung Yunanto ${ }^{a^{*}}$, Dara Sarasita $^{b}$, Defri Yona $^{b}$ \\ ${ }^{a}$ Balai Riset dan Observasi Laut, Bali \\ bIlmu Kelautan, Universitas Brawijaya Malang \\ *Koresponden penulis: ag.yunanto@gmail.com
}

\begin{abstract}
Abstrak
Sampah plastik merupakan sumber sekunder dari mikroplastik. Ukuran mikroplastik yang sangat kecil dapat menyerupai plankton dan mikroorganisme lainnya, sehingga berpotensi termakan oleh biota laut yang bersifat pasif seperti kerang. Mikroplastik yang terkandung dalam biota akan terakumulasi dan menyebabkan berbagai macam dampak. Penelitian ini dilakukan untuk menganalisa dan mengidentifikasi mikroplastik pada kerang Kijing (Pilsbryoconcha exilis) di Sungai Perancak, Bali. Analisa dan identifikasi dilakukan dengan 4 tahapan, yaitu preparasi sampel, perlakuan hidrogen peroksida, pemisahan massa jenis dan identifikasi mikroplastik secara visual. Hasil dari penelitian ini, ditemukan mikroplastik jenis fiber dan film pada sampel kerang. Mikroplastik jenis fiber paling banyak ditemukan pada sampel dibandingkan mikroplastik jenis film.
\end{abstract}

Kata Kunci : mikroplastik, kerang Kijing, Pilsbryoconcha exilis, jenis mikroplastik

\begin{abstract}
Plastik waste is a secondary source of microplastics. The very small size of microplastics can resemble plankton and other microorganisms, so that they have the potential to be eaten by passive marine biota such as shellfish. Microplastics contained in biota will accumulate and cause various kinds of impacts. This research was conducted to analyze and identify microplastics in shellfish (Pilsbryoconcha exilis) in the Perancak River, Bali. Analysis and identification were carried out in 4 stages, namely sample preparation, hydrogen peroxide treatment, density separation and visual identification of microplastics. The results of this study, found microplastic types of fiber and film in the shell samples. Fiber type microplastics are mostly found in samples compared to film type microplastics.
\end{abstract}

Keywords: microplastics, shellfish, Pilsbryoconcha exilis, type microplastics

\section{PENDAHULUAN}

Plastik digunakan secara luas dalam segala aspek kehidupan manusia karena keunggulannya [1]. Karakteristik yang terbilang unggul dari plastik diantaranya adalah ringan, kuat, tahan lama dan murah [2] yang membuat plastik sangat cocok digunakan untuk pembuatan berbagai macam produk. Dengan berbagai macam produksi plastik maka, limbah dari plastik pun akan tinggi mengikuti produksi yang ada [3].

Produksi plastik meningkat secara drastis di seluruh dunia selama 60 tahun terakhir, melewati 0,5 juta ton / tahun pada 1960 hingga mencapai 300 juta ton / tahun pada 2013 [4]. Saat ini, plastik merupakan bagian terbesar dari sampah yang ada di lautan. Dengan berat jenisnya yang khas, plastik merupakan penyusun sampah di laut hingga 90\% dari total sampah secara keseluruhan. Di Indonesia, kebutuhan plastik mencapai 1,35 juta ton per tahun pada tahun 2003, sedangkan hanya $20-30 \%$ yang mampu diolah kembali [5]. Plastik ditemukan di berbagai tempat di laut seperti pada garis pantai, mengapung di permukaan laut, melayang di kolom air serta menjadi limbah yang mendiami dasar lautan. Sampah plastik yang tersebar di perairan memiliki waktu yang lama untuk terdekomposisi. Uraian dari dekomposisi sampah plastik tersebut akan menjadi mikroplastik [6].

Sumber mikroplastik terbagi menjadi dua, yaitu primer dan sekunder [7]. Mikroplastik 
primer merupakan butiran plastik murni mencakup kandungan plastik dalam produkproduk pembersih dan kecantikan, pellet untuk pakan hewan, bubuk resin dan umpan produksi plastic [8]. Sementara itu, mikroplastik sekunder adalah mikroplastik yang dihasilkan akibat fragmentasi plastik yang lebih besar. Mikroplastik sekunder meliputi serat atau potongan hasil pemutusan rantai dari plastik yang lebih besar seperti jala ikan, kantong plastik, serta alat rumah tangga [9].

Jenis mikroplastik terbagi menjadi 4 , yaitu film, fiber, fragmen dan pellet [10]. Film merupakan polimer plastik sekunder yang berasal dari fragmentasi kantong plastik atau plastik kemasan dan memiliki densitas terendah (tipis, lembut dan transparan) ([11];[12]]. Fiber merupakan serat plastik memanjang dan berasal dari fragmentasi monofilament jaring ikan, tali dan kain sintetis. Fragmen merupakan hasil potongan produk plastik dengan polimer sintetis yang sangat kuat. Pellet merupakan mikroplastik primer yang langsung diproduksi oleh pabrik sebagai bahan baku pembuatan produk plastic [12].

Ukuran mikroplastik yang tergolong sangat kecil $(<5 \mathrm{~mm})([13] ;[14])$ dapat menyerupai plankton dan mikroorganisme lainnya. Mikroplastik dapat tertelan atau dimakan oleh biota laut, khususnya biota laut yang bersifat pasif. Invertebrata dengan berbagai macam metode makan diketahui menelan mikroplastik, termasuk filter feeder [15]. Salah satu biota yang berpotensi menelan mikroplastik adalah kerang yang merupakan filter feeder dan akan memakan apapun yang terfilter sesuai ukurannya [16]. Penelitian terdahulu menunjukkan bahwa partikel mikroplastik hadir dalam bivalvia seperti Mytilus edulis dan oysters (Crassoctrea gigas) [17]. Penelitian lainnya menunjukkan bahwa gooseneck barnacle (Lepas spp.) dari Pasifik Utara mengandung mikroplastik sebesar $33.5 \%$ dari total sampel yang diuji [18].

Mikroplastik yang tertelan atau termakan oleh biota tidak akan bisa dicerna dan akan menimbulkan dampak bagi biota tersebut. Plastik yang tertelan tidak memberikan nutrisi dan membuat biota kelaparan, mengalami kekenyangan palsu serta iritasi pada perut [19].
Hal ini tentu saja akan menghambat sistem pencernaan yang seiring berjalannya waktu akan membuat biota tersebut mati. Berdasarkan penelitian yang dilakukan oleh Rochman and Browne (2013)[20], dampak lain dari mikroplastik yang masuk ke dalam sistem pencernaan biota adalah dapat menyebabkan respon inflamasi pada jaringan dan mengurangi stabilitas membran sel dari sistem pencernaan pada kerang serta menyebabkan bioakumulasi, gangguan hati dan pembentukan tumor awal pada ikan medaka Jepang. Mikroplastik yang teridentifikasi pada organisme yang dikonsumsi oleh manusia akan memiliki potensi implikasi pada kesehatan manusia [18].

Penelitian ini dilakukan untuk menganalisa dan mengidentifikasi keberadaan mikroplastik pada kerang Kijing (Pilsbryoconcha exilis) yang berada di Sungai Perancak. Pencarian kerang kijing di Sungai Perancak sudah menjadi aktifitas penduduk setempat baik untuk di konsumsi ataupun hanya untuk mengisi waktu luang. Apabila kerang yang dikonsumsi tersebut mengandung mikroplastik dalam jumlah yang tinggi, maka memungkinkan untuk memberikan dampak yang tidak baik bagi manusia. Faktor lain yang mendukung penelitian ini adalah masih kurangnya penelitan yang dilakukan untuk menganalisa dan mengidentifikasi mikroplastik pada kerang, khususnya di Indonesia.

\section{Material dan Metode}

\section{Titik Pengambilan Sampel dan Metode Pengumpulan}

Sebanyak 30 sampel kerang diambil secara acak pada titik pengambilan sampel di sungai Perancak, Jembrana, Bali (Gambar 1). Pada titik lokasi tersebut banyak warga setempat yang mencari kerang kijing untuk dikonsumsi. Sampel kerang diambil tanpa menggunakan alat khusus, melainkan hanya menggunakan tangan dan kantong jaring sebagai wadah kerang. Pengambilan sampel dilakukan pada bulan Agustus 2017 saat perairan surut, sehingga memungkinkan untuk mencapai dasar perairan. Pengerjaan sampel dilakukan di Balai Riset dan 
Observasi Laut, tepatnya pada Laboratorium Kualitas Perairan, Bali.

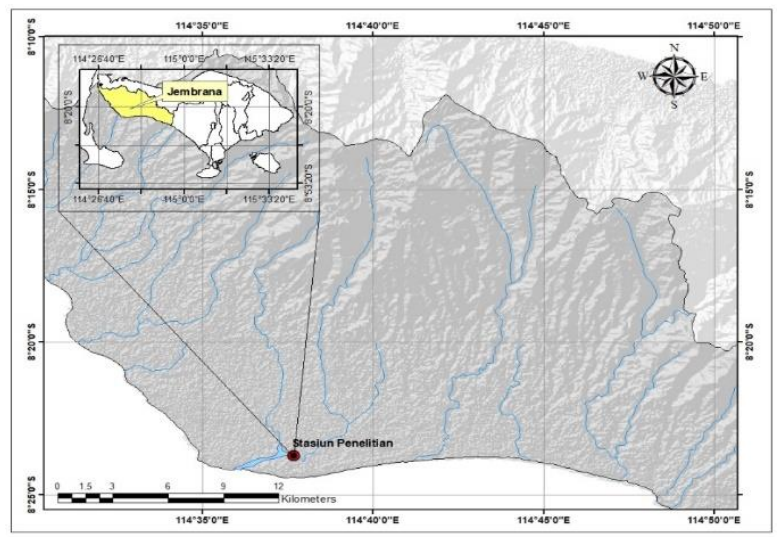

Gambar 1. Lokasi pengambilan sampel kerang di Sungai Perancak

\section{Metode Analisa Mikroplastik pada Kerang}

Setiap sampel kerang dianalisa kandungan mikroplastik yang terdapat di dalamnya dengan 4 tahap, yaitu preparasi sampel, perlakuan hidrogen peroksida, pemisahan massa jenis dengan menggunakan density separator, dan identifikasi mikroplastik secara visual. Tahapan awal yang dilakukan adalah preparasi sampel kerang. Langkah pertama yang dilakukan adalah membersihkan kerang dengan air mengalir. Tujuan dari langkah ini adalah agar seluruh kotoran (berupa sedimen) yang ada pada kerang tersapu dengan air. Langkah selanjutnya adalah mengukur panjang, lebar serta berat kerang dengan menggunakan penggaris dan timbangan digital untuk keperluan data morfologi kerang. Setelah itu, cangkang kerang dikupas dan sampel kerang ditumbuk secukupnya dengan menggunakan mortar dan alu. Penumbukkan ini bertujuan untuk memudahkan penghancuran bahan organik pada tahap selanjutnya.

Pada tahap kedua adalah wet peroxide oxidation (WPO). Sampel yang sudah disiapkan pada tahap preparasi diletakkan di dalam beaker glass 250 - $300 \mathrm{ml}$, kemudian ditambahkan larutan $\mathrm{Fe}$ (II) 0,05 M sebanyak $20 \mathrm{ml}$ ke dalam beaker glass berisi sampel. Larutan Fe (II) 0,05 M yang digunakan berfungsi sebagai larutan katalisator untuk mempercepat reaksi larutan. Setelah itu, ditambahkan $20 \mathrm{ml} \mathrm{H}_{2} \mathrm{O}_{2} 30 \%$ ke dalam beaker glass dan didiamkan selama 5 menit. Larutan $\mathrm{H}_{2} \mathrm{O}_{2} 30 \%$ berfungsi sebagai larutan pengurai bahan organik yang ada. Setelah didiamkan selama 5 menit, stir bar dimasukkan ke dalam beaker glass dan ditutup dengan kaca arloji. Setelah itu, beaker glass diletakkan diatas hotplate dan dipanaskan pada suhu $75^{\circ} \mathrm{C}$ dengan kecepatan putaran $270 \mathrm{rpm}$. Pemanasan dan pengadukkan ini dilakukan \pm selama 30 menit. Langkah selanjutnya adalah menambahkan 6 gr/ $20 \mathrm{ml} \mathrm{NaCl}$ pada larutan sampel. Ada beberapa catatan dalam tahapan ini, yaitu apabila muncul gelembung gas pada permukaan, beaker glass diambil dari hotplate dan diletakkan ke lemari asam hingga berkurang gelembungnya. Jika reaksi terjadi sangat cepat (berpotensi meluap dari beaker glass), aquades ditambahkan secukupnya untuk memperlambat reaksi. Apabila bahan organik masih ada, dilakukan penambahan $20 \mathrm{ml}$ larutan $\mathrm{H}_{2} \mathrm{O}_{2} 30 \%$. Penambahan larutan $\mathrm{H}_{2} \mathrm{O}_{2} 30$ $\%$ dilakukan sampai bahan organik tidak ada.

Setelah dari tahapan WPO, larutan dipindahkan dari beaker glass ke density separator. Untuk mempermudah pemindahan, beaker glass dibilas dengan aquades untuk memindahkan sisa padatan ke density separator (Gambar 2). Density separator ditutup dengan kaca arloji / cawan petri untuk melindungi larutan di dalamnya. Padatan dibiarkan turun dalam waktu semalam (mengendap). Padatan terapung disaring dengan menggunakan saringan $250 \mu \mathrm{m}$, kemudian dipindahkan ke dalam cawan petri. Padatan pada cawan petri dibiarkan di tempat terbuka sampai mengering. Catatan pada tahapan ini, pemakaian keran besi pada density separator dihindari agar larutan tidak bereaksi dengan keran.

Identifikasi mikroplastik pada tahapan ini menggunakan bantuan loop (kaca pembesar) pada colony counter. Penggunaan colony counter ini untuk mempermudah membedakan antara padatan mikroplastik dengan sisa bahan organik. Padatan yang diduga mikroplastik dipisahkan pada cawan petri. Mikroplastik dihitung dan diidentifikasi berdasarkan kelasnya (fiber, film, fragmen dan pellet). Setelah diidentifikasi, mikroplastik dipindahkan ke dalam botol vial. Untuk memastikan apakah padatan yang diduga 
adalah benar mikroplastik, padatan direndam pada $\mathrm{H}_{2} \mathrm{O}_{2} 30 \%$.

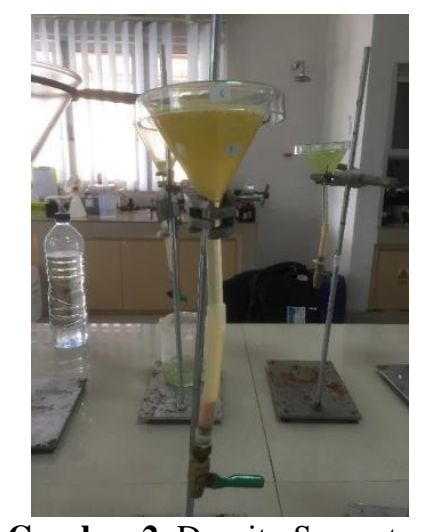

Gambar 2. Density Separator

\section{HASIL \& PEMBAHASAN}

Berdasarkan 30 sampel kerang yang digunakan, ditemukan mikroplastik pada 11 sampel kerang (37\%) dan tidak ditemukan mikroplastik pada 19 sampel kerang (63\%) (Gambar 3).

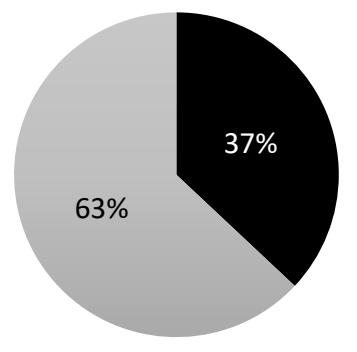

- Kerang yang mengandung mikroplastik

Kerang yang tidak mengandung mikroplastik

Gambar 3. Persentase mikroplastik pada kerang

Menurut Li et al., (2016) [21], karakteristik filter feeder yang terdapat pada bivalvia membuat biota tersebut terpapar secara langsung dengan mikroplastik yang ada di lingkungan. Hal tersebut membuat kerang secara otomatis akan menelan apapun yang tersaring ke dalam saluran pencernaannya termasuk mikroplastik. Namun, jumlah sampel kerang yang mengandung mikroplastik lebih sedikit dibandingkan dengan jumlah sampel kerang yang tidak mengandung mikroplastik. Hal tersebut dapat disebabkan oleh berbagai faktor, salah satunya adalah faktor lingkungan. Sungai Perancak merupakan sungai yang dikelilingi oleh hutan mangrove dan tidak terdapat pemukiman penduduk yang padat di sekitar sungai. Menurut Wagner et al., (2014) [22], perkiraan kasar memprediksi bahwa $70 \%$ sampai $80 \%$ dari sampah laut yang kebanyakan adalah plastik berasal dari darat dan disalurkan oleh sungai menuju ke laut. Hal tersebut menunjukkan perairan di Sungai Perancak tidak terlalu tercemar oleh sampah plastik dan membuat mikroplastik di perairan tersebut tidak melimpah, sehingga tidak semua kerang mengandung mikroplastik.

Hasil analisa mikroplastik pada kerang didapatkan 15 jenis fiber pada 8 sampel kerang dan 11 jenis film pada 10 sampel kerang yang diteliti (Gambar 4). Dari hasil tersebut, tidak terdapat mikroplastik jenis pellet maupun fragmen pada sampel kerang. Menurut Hastuti (2014)[12], mikroplastik jenis fragmen merupakan hasil potongan produk plastik dengan polimer sintetis yang sangat kuat. Sedangkan jenis pellet merupakan mikroplastik primer yang langsung diproduksi oleh pabrik sebagai bahan baku pembuatan produk plastik.

Dilihat dari lokasi penelitian yang dikelilingi oleh hutan mangrove dan digunakan sebagai lokasi pencarian ikan dan kerang, serta sering dilewati oleh kapal nelayan, maka tidak ditemukan mikroplastik jenis pellet yang bersumber dari bahan baku pembuatan produk plastik dan jenis fragmen yang merupakan potongan produk plastik yang sangat kuat seperti pipa dan produk plastik lainnya. Selain itu, hasil penelitian ini menunjukkan tidak ada hubungan yang cukup signifikan antara ukuran sampel kerang dengan jumlah dan jenis mikroplastik yang terkandung didalamnya. Hal tersebut dibuktikan dengan ditemukannya partikel mikroplastik pada hampir semua ukuran kerang dalam jumlah yang bervariasi.

Namun, jumlah tertinggi mikroplastik ditemukan pada sampel kerang dengan panjang $3,9 \mathrm{~cm}$, sedangkan sampel kerang dengan ukuran yang lebih kecil (kisaran 3,5-3,8 cm) dan ukuran sampel kerang yang lebih besar $(4 \mathrm{~cm}$ dan $4,2 \mathrm{~cm}$ ) memiliki kandungan mikroplastik yang jauh dibawahnya. Meskipun tidak banyak ditemukan 
pada sampel yang diteliti, keberadaan mikroplastik sudah terbukti dapat masuk ke dalam biota dan dapat menimbulkan berbagai macam dampak.

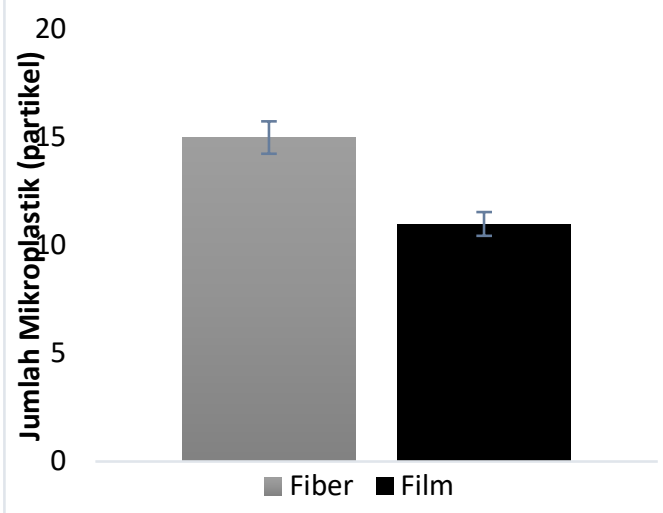

Gambar 4. Grafik Jumlah Mikroplastik

Mikroplastik yang paling banyak ditemukan adalah mikroplastik jenis fiber (Gambar 4), dimana fiber merupakan fragmentasi jaring ikan. Jumlah mikroplastik jenis fiber yang lebih banyak dibandingakan mikroplastik jenis film kemungkinan disebabkan oleh banyaknya warga setempat yang memancing di sungai tersebut, sehingga secara sengaja maupun tak sengaja dapat meninggalkan sampah alat pancingnya yang terfragmentasi menjadi mikroplastik. Jumlah mikroplastik jenis film lebih sedikit dibandingkan mikroplastik jenis fiber juga didukung oleh faktor lingkungan sungai yang tidak dipenuhi oleh sampah plastik.

\section{KESIMPULAN}

Mikroplastik yang ditemukan pada sampel kerang adalah jenis fiber dan film. Hal ini dikarenakan Sungai Perancak berada jauh dari pemukiman dan berada di habitat mangrove, sehingga tidak ditemukan jenis fragmen yang bersumber dari pecahan/ potongan plastik keras ataupun pellet yang bersumber dari limbah domestik dan limbah pabrik plastik. Mikroplastik jenis fiber yang ditemukan lebih banyak dibandingkan mikroplastik jenis film. Hal tersebut dikarenakan pada Sungai Perancak seringkali dilalui kapal-kapal kecil dan dikunjungi warga sekitar yang melakukan aktivitas memancing.
Alat-alat pancing yang dengan sengaja ataupun tidak terbuang ke perairan akan terurai menjadi mikroplastik jenis fiber yang pada akhirnya dapat masuk ke dalam biota.

\section{SARAN}

Penelitian ini merupakan penelitian pendahuluan yang dapat digunakan sebagai data pendukung untuk penelitian selanjutnya yang lebih mendalam. Penelitian mengenai mikroplastik pada kerang sebaiknya mempertimbangkan ukuran sampel kerang yang diambil.

\section{UCAPAN TERIMA KASIH}

Ucapan terima kasih disampaikan kepada semua pihak yang membantu terlaksananya penelitian ini, terutama kepada Maghfira Shafazamilla Mauludy dan Mardatilah, S.Si yang telah membantu dalam pengerjaan sampel di Laboratorium Kualitas Perairan Balai Riset dan Observasi laut (BROL), Bali.

\section{DAFTAR PUSTAKA}

[1] Kang, J.-H., Kwon, O.Y., Lee, K.-W., Song, Y.K., Shim, W.J., 2015. Marine neustonic microplastics around the southeastern coast of Korea. Mar. Pollut. Bull. 96, 304-312.

https://doi.org/10.1016/j.marpolbul.2015. 04.054

[2] Ivar do Sul, J.A., Costa, M.F., 2014. The present and future of microplastic pollution in the marine environment. Environ. Pollut. 185, 352-364. https://doi.org/10.1016/j.envpol.2013.10. 036

[3] Derraik, J.G., 2002. The pollution of the marine environment by plastic debris: a review. Mar. Pollut. Bull. 44, 842-852.

[4] Rios, L.M., Moore, C., Jones, P.R., 2007. Persistent organic pollutants carried by synthetic polymers in the ocean environment. Mar. Pollut. Bull. 54, 12301237.

https://doi.org/10.1016/j.marpolbul.2007. 03.022 
[5] Anas, S., Salma, A., Nugroho, F., Linguistika, Y., Filinoristi, W., 2010. Metode penelitian. Jakarta: Rajawali Pers.

[6] Galgani, F., Hanke, G., Maes, T., 2015. Global Distribution, Composition and Abundance of Marine Litter, in: Bergmann, M., Gutow, L., Klages, M. (Eds.), Marine Anthropogenic Litter. Springer International Publishing, Cham, pp. 29-56. https://doi.org/10.1007/978-3319-16510-3_2

[7] Cole, M., Lindeque, P., Halsband, C., Galloway, T.S., 2011. Microplastics as contaminants in the marine environment: A review. Mar. Pollut. Bull. 62, 25882597.

https://doi.org/10.1016/j.marpolbul.2011. 09.025

[8] Gregory, M.R., 1996. Plastic 'scrubbers' in hand cleansers: a further (and minor) source for marine pollution identified. Mar. Pollut. Bull. 32, 867-871.

[9] Browne, M.A., Crump, P., Niven, S.J., Teuten, E., Tonkin, A., Galloway, T., Thompson, R., 2011. Accumulation of Microplastic on Shorelines Woldwide: Sources and Sinks. Environ. Sci. Technol. 45, 91759179. https://doi.org/10.1021/es201811s

[10] Free, C.M., Jensen, O.P., Mason, S.A., Eriksen, M., Williamson, N.J., Boldgiv, B., 2014. High-levels of microplastic pollution in a large, remote, mountain lake. Mar. Pollut. Bull. 85, 156-163. https://doi.org/10.1016/j.marpolbul.2014. 06.001

[11] Jabeen, K., Su, L., Li, J., Yang, D., Tong, C., $\mathrm{Mu}$, J., Shi, H., 2017. Microplastics and mesoplastics in fish from coastal and fresh waters of China. Environ. Pollut. 221 , 141-149. https://doi.org/10.1016/j.envpol.2016.11. 055

[12] Hastuti, A.R., 2014. Distribusi Spasial Sampah Laut Di Ekosistem Mangrove Pantai Indah Kapuk Jakarta. Institut Pertanian Bogor, Bogor.

[13] Betts, K., 2008. Why small plastic particles may pose a big problem in the oceans.
Environ. Sci. Technol. 42, 8995-8995. https://doi.org/10.1021/es802970v

[14] McCormick, A., Hoellein, T.J., Mason, S.A., Schluep, J., Kelly, J.J., 2014. Microplastic is an Abundant and Distinct Microbial Habitat in an Urban River. Environ. Sci. Technol. 48, 11863-11871. https://doi.org/10.1021/es503610r

[15] Farrell, P., Nelson, K., 2013. Trophic level transfer of microplastic: Mytilus edulis (L.) to Carcinus maenas (L.). Environ. Pollut. 177, 1-3. https://doi.org/10.1016/j.envpol.2013.01. 046

[16] Van Cauwenberghe, L., Claessens, M., Vandegehuchte, M.B., Janssen, C.R., 2015. Microplastics are taken up by mussels (Mytilus edulis) and lugworms (Arenicola marina) living in natural habitats. Environ. Pollut. 199, 10-17. https://doi.org/10.1016/j.envpol.2015.01. 008

[17] Van Cauwenberghe, L., Janssen, C.R., 2014. Microplastics in bivalves cultured for human consumption. Environ. Pollut. 193, 65-70. https://doi.org/10.1016/j.envpol.2014.06. 010

[18] Avio, C.G., Gorbi, S., Regoli, F., 2017. Plastics and microplastics in the oceans: From emerging pollutants to emerged threat. Mar. Environ. Res. 128, 2-11. https://doi.org/10.1016/j.marenvres.2016 .05 .012

[19] Moore, C.J., 2008. Synthetic polymers in the marine environment: A rapidly increasing, long-term threat. Environ. Res. 108, 131-139. https://doi.org/10.1016/j.envres.2008.07. 025

[20] Rochman, C.M., Browne, M.A., 2013. rochman2013.pdf.

[21] Li, J., Qu, X., Su, L., Zhang, W., Yang, D., Kolandhasamy, P., Li, D., Shi, H., 2016. Microplastics in mussels along the coastal waters of China. Environ. Pollut. 214, $177-184$. 
https://doi.org/10.1016/j.envpol.2016.04.

012

[22] Wagner, M., Scherer, C., Alvarez-Muñoz, D., Brennholt, N., Bourrain, X., Buchinger, S., Fries, E., Grosbois, C., Klasmeier, J., Marti, T., 2014. Microplastics in freshwater ecosystems: what we know and what we need to know. Environ. Sci.

Eur. 26, 12. 